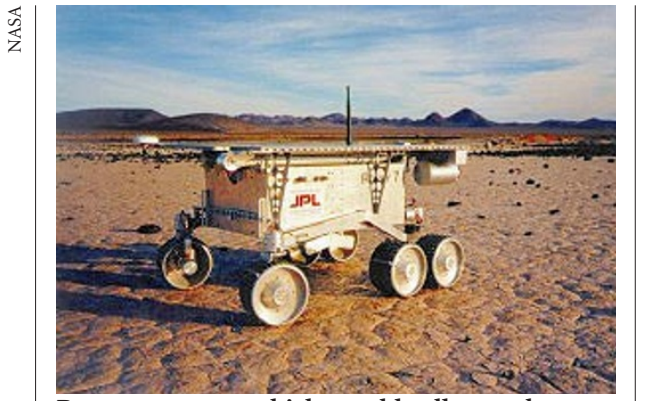

Rover returns: a vehicle would collect rock samples to be brought back to Earth.

1997). CNES has been encouraged by French research minister Claude Allègre — himself a geologist who took part in analysis of the moon rocks - to play a large and consistent role in the international Mars programme and to do so it is prepared to forge significant bilateral agreements. This is a situation that secretly worries the ESA considerably, since bilateral agreements inevitably compete for national funding with scientific instruments for ESA missions.

Mars Express, a lander/orbiter mission scheduled for launch in 2003, may also include international collaboration. ESA and NASA have been discussing an Italian idea whereby a communications link on the Mars Express spacecraft would be used for the US sample return mission in 2005. So far, however, no agreements have been signed.

CNES and NASA are farther along in discussing what McCleese calls joint "precursor mini-missions" to Mars, which would be piggybacked on Ariane 5 launches that deliver commercial satellites to high geostationary orbits. These missions, which would run in addition to NASA's already planned Mars programme, could deliver between 80 and $160 \mathrm{~kg}$ of payload to the Martian surface beginning as early as 2000 .

France would provide the Ariane 5 piggyback ride and an upper stage rocket, while NASA would provide the spacecraft. The scientific instruments would be developed jointly. Each mission would cost between $\$ 25$ million and $\$ 50$ million, and would be able to land simple instruments such as small probes or penetrators on the surface of Mars.

McCleese says the mini-missions would be ideal for positioning networks of sensors that could collect seismological and meteorological data. "It's something we've been working on for 20 years," he says.

US funding for these mini-missions would have to come out of NASA's existing Mars programme, which is budgeted at about $\$ 1$ billion over 10 years. The missions might also be accommodated within the agency's Discovery line of small and inexpensive planetary missions. As with collaboration on the sample return, no agreement has been reached yet. But McCleese believes the mini-missions have "a very high probability of happening".

Tony Reichhardt

\section{Quebec says yes to federal money for infrastructure}

[MONTREAL] The separatist government of the Canadian province of Quebec has bent its sovereignty principles to gain access to some of the C\$800 million (US\$560 million) of research infrastructure funding being offered by the federal government.

But the move has not been made without protest. And it remains unclear how far the province is likely to go in imposing what it has described as its own priorities on the way the money is used.

The funds are being made available through the Canada Foundation for Innovation (CFI), which was set up last year in the federal budget using money released as a result of a tight fiscal policy (see Nature 385, $759 ; 1997)$. It was hoped that the funds would help to attract back to the country Canadian researchers working abroad.

Project proposals were invited from universities and hospitals across the country, but Quebec's education minister, Pauline Marois, condemned this in December as an example of federal intrusion in a provincial jurisdiction.

Education and the administration of health services are provincial responsibilities in Canada (although these are not the only areas in which Quebec frequently complains about federal intrusion). Marois demanded that Quebec's share of the C $\$ 800$ million be handed directly to the province, and even threatened to penalize institutions that might respond to the CFI's invitation.

When the federal government saw the contradiction in Quebec policy, its industry minister, John Manley, sent a letter to Marois and Quebec's health minister Jean Rochon accusing the province of playing petty politics.

At a news conference, Quebec's intergovernmental affairs minister, Jacques Brassard, revealed his government's underlying philosophy when he described the "ideal situation" as being able to say to the federal government: "It's none of your business. We don't want you in Quebec and we don't want your money."

But Brassard added that sometimes it is necessary to be pragmatic. A modified procedure has now been developed under which Quebec universities and hospitals will submit their projects to the CFI through the Quebec government.

One reason for Quebec's stance is that like the other provinces - it will have to pay overhead costs, and perhaps provide matching funds, for any projects funded by the CFI. For some years, all provinces have suffered drastic cuts in federal transfer funds in education and health fields.

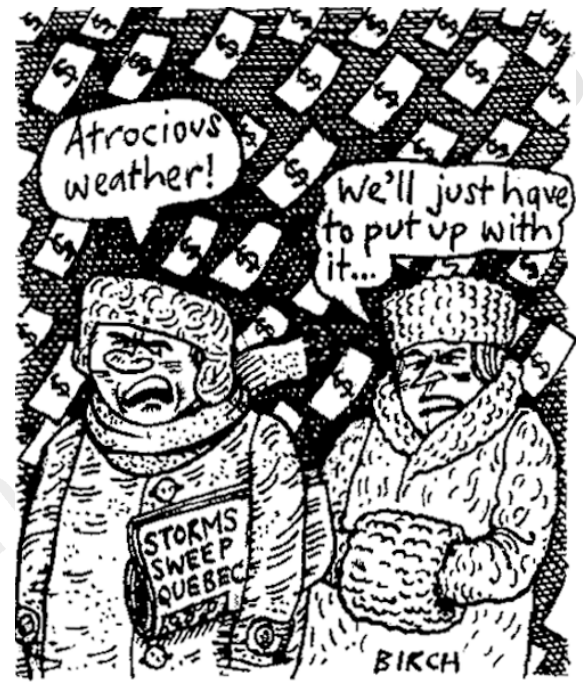

Denis Gagnon, acting president and chief executive officer of CFI, says that, like many researchers, he was greatly disappointed by the initial stance of the Quebec government.

He says Quebec came to the press conference at which Brassard made his comments with both a political issue and an operational issue. "The political issue I have nothing to do with," said Gagnon. "It's between governments."

He admits that all provinces are concerned about the question of operating costs, and will be meeting their representatives in the next few weeks to talk about the issue.

"I will be discussing with the provinces what we want to do and how we could work together in such a way that we will fund what they want."

Gagnon thinks it unlikely that the provinces will seek to impose their own priorities on research institutions, and is keen to receive applications that have the support of these governments as well as their institutions. But he admits he does not know how this might come about.

For example, Quebec might ask its own two fund-granting institutions, or some sort of committee, to consider the applications before they go to the CFI.

Gagnon says it is unclear what the Quebec government meant when it said that applications should accord with "our priorities".

"It's clear from the original funding agreement between CFI and the federal government that we would like to have the universities and hospitals establish their [own] priorities, and then tell us what they are," he said. "My feeling is that this is what will happen."

David Spurgeon 